\title{
THE UTILISATION OF ISLAMIC FINTECH (I-FINTECH) IN PROMOTING SUSTAINABLE INCLUSIVE GROWTH: EVIDENCE FROM MICRO-ENTREPRENEURS IN MALAYSIA
}

\author{
Nik Hadiyan Nik Azman ${ }^{1}$, Mohd Zaidi Md. Zabri², Tajul Ariffin Masron³ and \\ Nurhafiza Abdul Kader Malim ${ }^{4}$ \\ ${ }^{1}$ School of Management, Universiti Sains Malaysia, Malaysia, nikhadiyan@usm.my \\ ${ }^{2}$ Faculty of Business and Accountancy, University of Malaya, Malaysia, zaidizabri@um.edu.my \\ ${ }^{3}$ School of Management, Universiti Sains Malaysia, Malaysia, tams@usm.my \\ ${ }^{4}$ School of Management, Universiti Sains Malaysia, Malaysia, fizanur@usm.my
}

\begin{abstract}
Information technology is fundamentally changing the world today. The power of technology applicable fastly in Islamic financial technology (i-Fintech), as it expands access to mobile financial services. This is evidenced by the increasing number of customers who interact using technology, especially micro-entrepreneurs, who adopt the tools into their business models to tap into this opportunity to enhance their income. Therefore, it is imperative to examine the impact of i-fintech use in stabilising microentrepreneurs' income. A quantitative technique was employed through the use of 120 questionnaires distributed to micro-entrepreneurs who had adopted i-fintech into their business. Using Amos and SEM models, the study indicates that crowdfunding, mobile money and peer-to-peer lending play a significant role in ensuring income sustainability for micro-entrepreneurs. The study also discusses both the theoretical and managerial implications in comprehending the determinants of sustainable income growth in Malaysia. The findings should help practitioners, researchers and regulators to have better understanding of the dynamics between the potential of i-fintech and sustainable income.
\end{abstract}

Keywords: Income stability, Micro-entrepreneurs, Islamic fintech. JEL Classification: G20; G21; G23.

\author{
Article history: \\ Received : October 8, 2019 \\ Revised : December 6, 2019 \\ Accepted : July 16, 2020 \\ Available online : August 25, 2020
}

https://doi.org/10.21098/jimf.v6i3.1180 


\section{INTRODUCTION}

\subsection{Background}

Information technology (IT) is becoming a major aspect of business activities, having a significant impact on the stability of a country's economy (Oseni et al., 2019). The fundamentals of IT are changing the world today and transforming the business model, especially that of financial institutions. Structure, operations and management teams will automatically change according to the current needs of the different layers of society. According to the Islamic Fintech report 2018, Asian countries have the highest number of internet users, at around 2.275 million users, compared to other parts of the world. As Malaysia is an Asian country in the ASEAN region, it is essential to consider internet users in such countries (Figure 1).

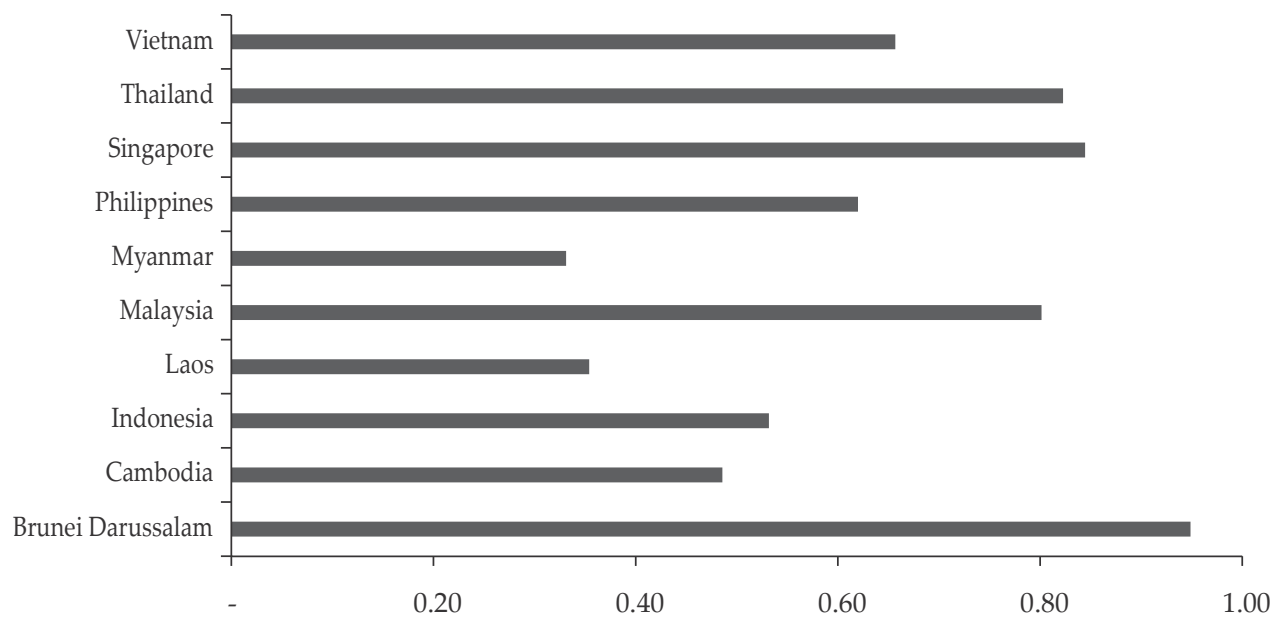

Source: World Internet User Statistics (2019)

Figure 1.

Internet Users in ASEAN Countries (as a ratio)

Based on Figure 1, Malaysia is among the top five countries in terms of internet usage. Therefore, the onus is on fintech companies to penetrate the Malaysian market. In addition, the business landscape is changing due to advances in technology. Dash and Bhusan (2014) contend that the incorporation of technologies and mobile networks has created new balances and applications for businesses. Besides, smartphones and tablets are increasingly being used for faster delivery mechanisms (Lee et al., 2015). Customers no longer need to visit physical outlets as they have the digital option available for them to use at any time.

Meuter et al. (2000) state that markets have become increasingly reliant on technology to facilitate transactions. The increasing numbers of customers who interact using technology will create long-term success for businesses. Besides, fintech has been widely accepted as a medium for financial transactions. Tapping into this, fintech is approaching society by offering new products, services and technology, which indirectly have an impact on monetary stability, financial system stability, efficiency, smoothness, security, and payment system reliability 
(Hui et al., 2019). Fintech is not a bank, but plays an essential role in economic development and the financial system. The World Bank has been promoting fintech as a conduit for financial development, which is attributable to strong economic growth (Beck, Demirguc-Kunt, \& Levine, 2004).

Besides, a growing body of research has revealed various potential developments based on fintech, such as the provision of new sources of profits from high sales volumes and lower transaction costs (Costa \& Ehrbeck, 2015), accelerating the implementation of risk-sharing (Alaabed \& Mirakhor, 2017), and the positive perceptions of SMEs and start-ups towards fintech instruments (Ghazali \& Yasuoka, 2018). In addition to providing benefits, fintech also has a comprehensive set of applications available on the market, such as financing and asset management payments. Table 1 shows the fintech services and platforms that are currently available on the market.

Table 1.

Fintech Solutions and Platforms

\begin{tabular}{lcc}
\hline Service & Platform & Remarks \\
\hline Mobile Money & $\begin{array}{c}\text { Digital payments; } \\
\text { e-wallets }\end{array}$ & $\begin{array}{c}\text { Mobile money can be classified as transactions } \\
\text { made without having an account with a financial } \\
\text { institution }\end{array}$ \\
\hline P2P lending & Micro-lending & $\begin{array}{c}\text { Social lending that matches borrowers and lenders } \\
\text { via online platforms }\end{array}$ \\
\hline Trading Platforms & Donations; equity & $\begin{array}{c}\text { The raising of small amounts of money for certain } \\
\text { project from a pool of people via online platforms }\end{array}$ \\
\hline Blockchain & $\begin{array}{c}\text { Robo-advisors use algorithms to propose a mix } \\
\text { of assets to invest in, based on a customer's } \\
\text { investment preferences and features }\end{array}$ \\
\hline
\end{tabular}

Source: Authors' compilation (2019)

The diversification of fintech services, products and applications does not guarantee that transactions comply with Syariah law. There is an urgent need to relevancies Syariah that is innovation-friendly. Serving billions of Muslims around the world, the innovativeness of products and services should be more advanced than in conventional systems. Therefore, technology adoption should be credited as having a positive effect on Islamic financial institutions, especially Islamic banking. Technology can have a significant impact on transparency, which will enable all stakeholders, such as bankers, Islamic courts and customers, to view the transactions that take place in the Syariah banking environment.

Taking fintech's advantages into consideration, Islamic finance may finally be able to penetrate what has previously been termed as "unbankable" areas (Mohammed \& El Amri, 2019) through i-fintech. The initial goal of such penetration is to cater for the needs of the ummah, providing transactions do not breach Islamic rules and regulations. As discussed by Todorof (2018), the most important Syariah principles recognized by all Muslims are based on the notion that the interests of the community take precedence over those of the individual. This means that the benefits of the ummah take precedence over those of individuals. 
Islamic financial technology is one of the by-products of the rapidly changing globalised world, which has influenced and expanded the reach of traditional markets. This progressive development is supported by excellent market infrastructures, supportive regulatory bodies, and the active participation of industry players. The evolution of fintech has unlocked a world of possibilities for Islamic financial institutions (IFIs). Although i-fintech is still in its infancy, with small and limited investment in sectors, it has been widely accepted on a global scale. For example, as reported by the Islamic Fintech report (2018), 90 Islamic fintech company startups globally are delivering financial solutions to customers. 65 of these are providing peer-to-peer technology solutions to facilitate consumer and business financing, and a further 14 are enabling deposits and transfers via blockchain technology.

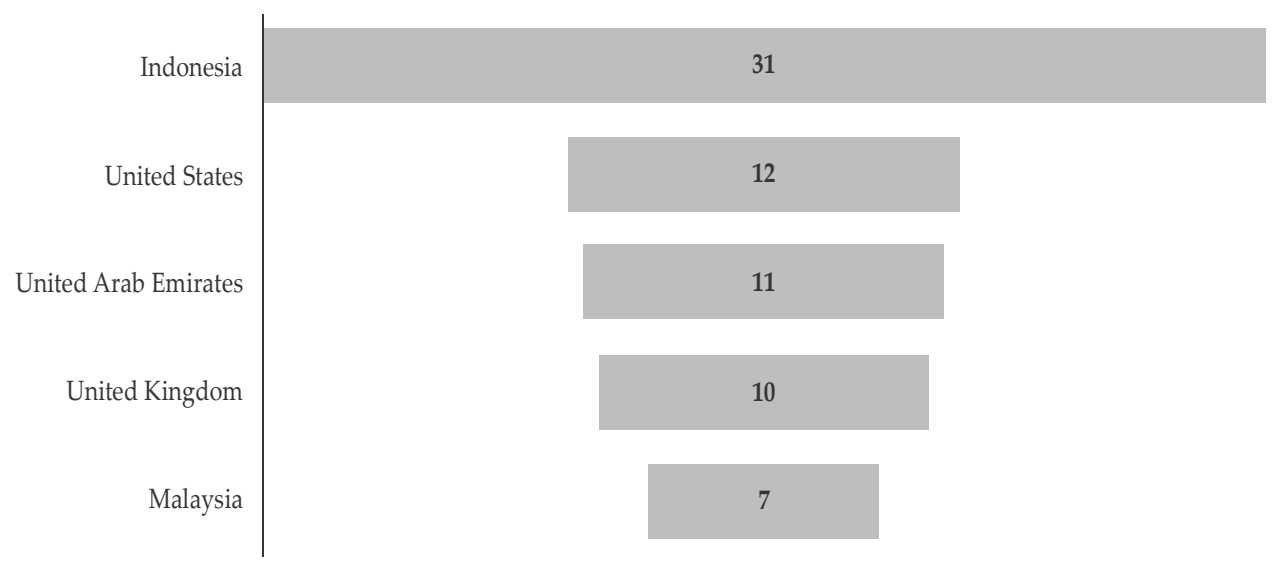

Source: Islamic Fintech Report (2018)

Figure 2.

Islamic Fintech Start-ups by Country

As can be seen in Figure 2, the highest number of Islamic fintech start-ups in Muslim-majority countries is in Indonesia, followed by the UAE and Malaysia. The figure also shows that the size of the economy may have a correlation with the number of fintech start-ups. Interestingly, the United States and the United Kingdom, which are Muslim-minority countries, also host a large number of Islamic fintech companies, primarily in promising areas such as crowdfunding, peer-to-peer (P2P) lending and digital wealth management.

Considering the potential of Islamic fintech for businesses, it provides a great opportunity, especially for micro-entrepreneurs, to tap into the Islamic fintech ecosystem. As shown in Figure 3, the highest demand for Islamic fintech is from businesses that constitute more than three-quarters of the chart. Therefore, microentrepreneurs need to digitise their businesses to tap into what i-fintech might be able to offer, which is also in line with the Malaysian government's vision to encourage micro-entrepreneurs to incorporate more fintech elements into their business operations. 


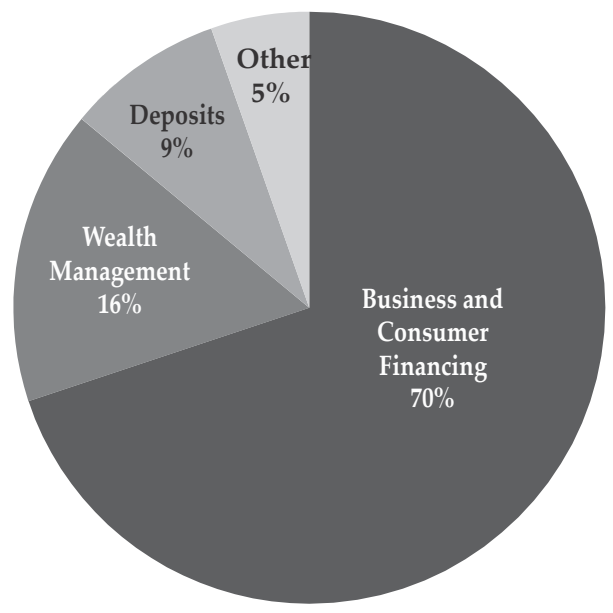

Source: Islamic Fintech Report (2018)

Figure 3.

Islamic Fintech Demand Breakdown by Function

Recently, the Malaysian government has imposed more stringent rules and guidelines on micro-entrepreneurs with regard to loans and funding due to high risk (low scale) investment, and lack of knowledge of fund management. As a result, i-fintech could be the potential financing avenue for micro-entrepreneurs. Therefore, considering many potentialities of i-fintech, this study intends to investigate the push for sustainable income through the use of $i$-fintech business apps among micro-entrepreneurs in Malaysia.

There has been an urgent call for potential justification of how and to what extent financial technology has been successful in easing the liquidity constraints of customers, especially micro-entrepreneurs.

\subsection{Objective}

The study focuses on i-fintech tools such as mobile money, mobile transfer, P2P lending, and crowdfunding applications. This focus is in line with what the Fintech Global Survey of 2017 outlined as major fintech applications; for example, payments $(21 \%)$ and fund transfers $(17 \%)$. Moreover, most micro-entrepreneurs have limited literacy in other types of fintech applications (Islamic Fintech Report, 2018).

\section{LITERATURE REVIEW}

\subsection{Background Theory}

\subsubsection{Technology Acceptance Model}

This study applies the theory proposed by Fred Davis in 1989 known as Technology Acceptance Theory (TAM). TAM is considered to be a useful model for its ability to include both human and social change factors in relation to the adoption of innovation. One of the many relative advantages of the theory is its 
ability to explain why users accept or reject new technology (Szajna, 1996). In addition, it is valid and robust, as it has been used widely in the research field because of its understandability and simplicity (King \& He, 2006). Considering the model proposed by Fishbein and Ajzen, TAM has the power to trace the impact of external variables on internal beliefs, attitudes and intentions. In fact, TAM also incorporates elements of physical experience. In consideration of this, TAM is used as the underlying theory for this study. The study design employs technology users (i-fintech: crowdfunding, peer-to-peer lending, and mobile money) as factors influencing sustainable financing (income).

\subsubsection{Micro, Small and Medium Sized Enterprises in Malaysia}

In Malaysia, according to the National SME Development Council (2019), the definition of micro-enterprises (MEs) is based on two criteria: the number of fulltime employees and annual sales turnover. Such establishments have fewer than five employees or a sales turnover lower than RM 300,000 for the manufacturing sector and RM 300,000 for other sectors, namely agriculture, mining, quarrying, construction, and services. MEs play an essential role in the Malaysian economy and could be considered as the backbone of industrial development in the country (Khalique, 2011; Fuad \& Bohari, 2011; Darmansyah, 2013). They now provide around 65 percent of total employment, and it is expected that their value-added production will be around RM 120 billion, or 50 percent of total production, by 2020 (SME Corporation Malaysia, 2019).

Moreover, according to the latest statistics from the Economic Census (2016) of the Department of Statistics Malaysia, an increasing number of individuals are becoming entrepreneurs, most of whom are involved in micro-enterprises. Specifically, out of the 907,065 small and medium enterprises (SMEs) in Malaysia, 691,527, or 6.6\%, were micro-entreprises (Department of Statistics, 2017). The group is playing an increasing role in the economy and has started to make positive contributions to its development (Fuad \& Bohari, 2011; Darmansyah, 2013).

Table 2.

Census of Establishments and Enterprises, 2011 and 2016

\begin{tabular}{lcc}
\hline $\begin{array}{l}\text { Type/ } \\
\text { Census }\end{array}$ & $\begin{array}{c}\text { Census of Establishments and } \\
\text { Enterprises 2011 }\end{array}$ & $\begin{array}{c}\text { Census of Establishments and } \\
\text { Enterprises 2016 }\end{array}$ \\
\hline Micro & 496,458 & 691,527 \\
Small & 128,787 & 192,013 \\
Medium & 19,891 & 23,525 \\
Total & 645,136 & 907,065 \\
\hline
\end{tabular}

Source: Department of Statistics Malaysia (2019)

\subsection{Previous Studies}

This study empirically reviews several i-fintech applications among microentrepreneurs in Malaysia, including, among others, mobile money, mobile transfer, peer-to-peer lending, and crowdfunding. 


\subsubsection{Sustainable Income}

Sustainable entrepreneurship can be defined as the continuing business contribution towards economic development, while enhancing the quality of life of the family and community (Young \& Tiller, 2005). Business sustainability also can be considered as continuous innovation in business implementation in achieving specific business goals. Sustainable entrepreneurship has a positive association with a sustainable income. As defined by Azman et al. (2017), sustainable income indicates whether any revenue earned was sufficient to cover both direct costs, such as those of financing, provisions for loan losses, and operating expenses, and indirect costs, such as the adjusted cost of capital.

As documented by Alufohai (2006) and Nik Azman et al. (2016), financial sufficiency best correlates with reasonable rates, availability of voluntary saving facilities, frequency of loan collections, and managerial ability to move organisations towards self-sufficiency. Kaplinsky (2019) argues that the ability to use technology is necessary in order to raise sufficient capital, both at startup and onward, to keep the business running smoothly, as loan size represents business liquidity. Therefore, it is important to consider the factors related to i-fintech utilisation with regard to sustainable income among micro-entrepreneurs.

\subsubsection{Crowdfunding}

Crowdfunding is a newly emerging phenomenon. It has gained popularity during the last few years as a method of seeking financing (Forbes et al., 2012). As the name implies, it can be defined as an initiative taken to raise money from several people (a crowd) (Ordanini et al., 2011). According to Schwienbacher and Larralde (2010), the basic idea of crowdfunding is to raise external finance from a large audience (the crowd). The individuals, investors or customers that make up the "crowd" are called crowdfunders and usually pool their money together via an online platform.

With regard to Islamic crowdfunding, it must adhere to several defining characteristics compared to its conventional counterparts. First, the investors and the fund must place strong emphasis on responsibility and Syariah compliance. Second, investors must place common emphasis on the core value of Islamic products through both quality and ethical principles. For example, it is compulsory for projects to adhere to Islamic principles and companies (start-ups) are strictly prohibited from taking Riba' (surplus payments). Third, profit and loss-sharing (PLS) concepts need to be applied throughout the project to ensure a fair distribution between crowdfunders and entrepreneurs. Moreover, while dealing with Syariah crowdfunding, specific Syariah screening and legal formalities also need to be embedded.

There are several types of Islamic crowdfunding (Griffin, 2012): donation-based (without any reward besides benevolence); reward-based (with non-financial rewards such as products, services, or promotion); lending-based (with financial returns such as interest); and equity-based (with financial returns such as equity, equity-like shares or dividends). The principal distinction between these four forms of crowdfunding is the value of crowdfunded received for their funding . 
According to Hemer et al. (2011), crowdfunding can be employed during the early stages of a business life cycle and may thus act as an opportunity to close the early-stage gap. Most individuals that crowdfund are entrepreneurs. Studies by Belleflamme et al. (2013) and Gerber et al. (2012) found that entrepreneurs are more inclined to crowdfund as their main financing channel compared to use of conventional banking institutions. They performed semi-structured interviews with market participants and identified five categories of motivation: financing, forming relationships and networks, self-affirmation, replication of success stories, and increased awareness of the product. However, instead of focusing on how much money the crowdfunding process may achieve, the all-important element that needs to be considered is how and to what extent the financing is able to sustain the income and growth of micro-entrepreneurs. Therefore, it is hypothesised that: H1: Crowdfunding (CF) has a positive and significant relationship with sustainable income (SI) for micro-entrepreneurs.

\subsubsection{Mobile Money}

Mobile money (for example, credit card use on mobile websites, QR codes, and mobile phone card readers) can be defined as the process of transmitting money from one person to another by phone or any wireless or computer device activation code, that finally can transact with a cash transaction by a financial or banking institutions. According to Shaikh and Karjaluoto (2014), Nel and Boshoff (2014), Talukder, Quazi, and Sathye, (2014) and Yang et al. (2015), mobile money is a product or service offered by banks for both financial and non-financial transactions using mobile devices. Mobile money from the Islamic perspective can be examined based on the alignment of these tools with religious beliefs and values. Operators of Islamic mobile money need to avoid engaging with organisations involved in gambling, alcohol, pornography, pork or weapons (Thye Goh et al., 2014).

These scholars identify mobile money as interactive transactions, through which customers can execute financial and non-financial transactions. Rinder and Fiserv (2016) indicate that mobile money has the potential to increase revenue for those who adopt it, as both customers and businesses benefit from the cheaper delivery channel. Moreover, mobile money also helps to provide low cost and more convenient transaction channels, which allows customers to operate quickly (Anderson, 2010). These services improve the experience of customers looking for streamlined payments. Therefore, it is hypothesised that:

$\mathrm{H} 2$ : Mobile money (MM) has a positive and significant relationship with sustainable income (SI) among micro-entrepreneurs.

\subsubsection{Peer-to-Peer (P2P) Lending}

Peer-to-peer lending, also known as crowdlending or social lending, functions as a non-intermediary type of debt financing. This platform allows individuals to connect with others to borrow and lend money between themselves. In Islamic terms, P2P is based on risk-sharing or risk-transferring, which is Syariah compliant. As a modification to the traditional banking system, P2P matches borrowers who 
are seeking financing with investors, who obtain a revenue from a share of the service charges that borrowers pay for the financing. Platforms operate by assisting in the collection, scoring and distribution of the credit qualifications of potential borrowers, reporting real-time bids on projects, and supplying online servicing and monitoring of loans (Morse, 2015). Such lending is experiencing significant growth in the United Kingdom and United States.

P2P enables modern investors to have direct access to an asset class that was previously limited to large institutional investors, which may allow them to diversify their portfolios and create enhanced risk-adjusted returns through the savings achieved by a lower-cost operating model (Feng et al., 2015). The beneficial aspects of P2P lending seem to have been also appreciated by Muslim entrepreneurs. One example of a Muslim platform for P2P lending was founded in June 2017 by Yusuf Mansur in Indonesia, who was able to bridge the gap between small and micro-entrepreneurs, mostly comprising young adults (30 years old).

In early 2016, the Malaysian government introduced the Investment Account Platform (IAP) to bring together projects in need of funding and investors. Through this platform, the bank plays a monitoring role to ensure any given project complies with Syariah, screen project viability, and assign credit ratings. At the same time, the Malaysian government also spends about 47.8 million, which is classified under the Working Capital Guarantee Scheme (WCGS) fund, to assist micro-entrepreneurs in becoming more accustomed to Islamic financial technology innovation. Bank Negara Malaysia also created a regulatory sandbox framework for Islamic financial technology to "enable innovation of fintech to be deployed and tested in a live environment, within specified parameters and timeframes" (Bank Negara Malaysia, 2016, p. 1). This shows that the Malaysian government is taking serious steps to incorporate Islamic financial technology by involving the market players and regulators. However, the ability of P2P to stabilise income for micro-entrepreneurs has yet to be investigated. Therefore, it is hypothesised that: H3: Peer-to-peer lending (P2P) has a positive and significant relationship with sustainable income (SI) for micro-entrepreneurs.

\subsection{Conceptual Framework}

Based on the literature review presented, a framework has been designed and developed, as shown in Figure 4. Since the study of fintech, especially Islamic fintech, is still in its infancy, literature on Islamic fintech in particular is scarce. Figure 4 shows the proposed framework for the link between i-fintech innovation and income sustainability. 


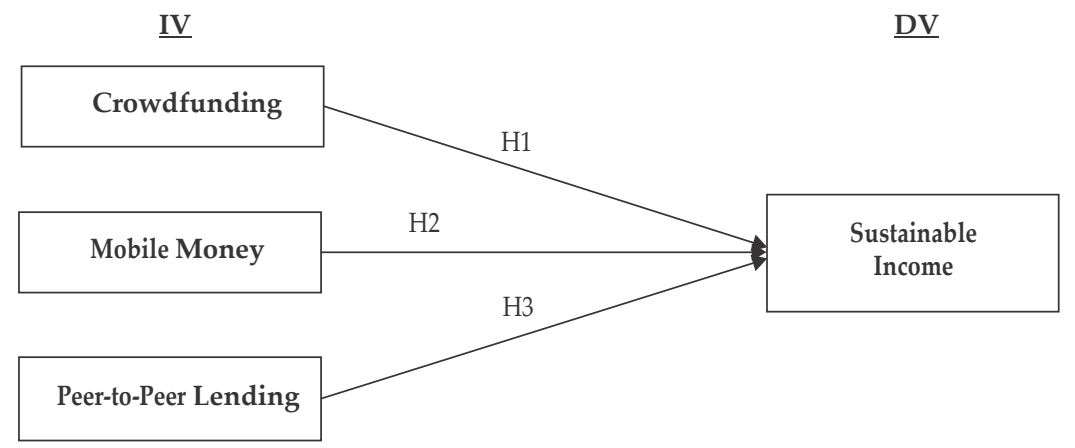

Figure 4 .

Proposed i-Fintech Framework

\section{METHODOLOGY}

\subsection{Data}

It is generally regarded that 100 is the practical minimum size for using SEM . Hair et al. (2010) suggest this level when considering models containing five or fewer constructs, each with more than three items with high item communalities (0.6 or higher); but 150 when models contain seven or fewer constructs and modest communalities (0.5), and 500 when models contain a large number of constructs, some with lower communalities. These suggestions informed the sample size for this study, which comprises about 100 respondents. Developing Hair et al.'s (2010) proposals, this study also applied power analysis (G*Power) to determine the adequate sample size for the study at a $95 \%$ confidence level in order to analyse the data. It shows adequate data for analysis.

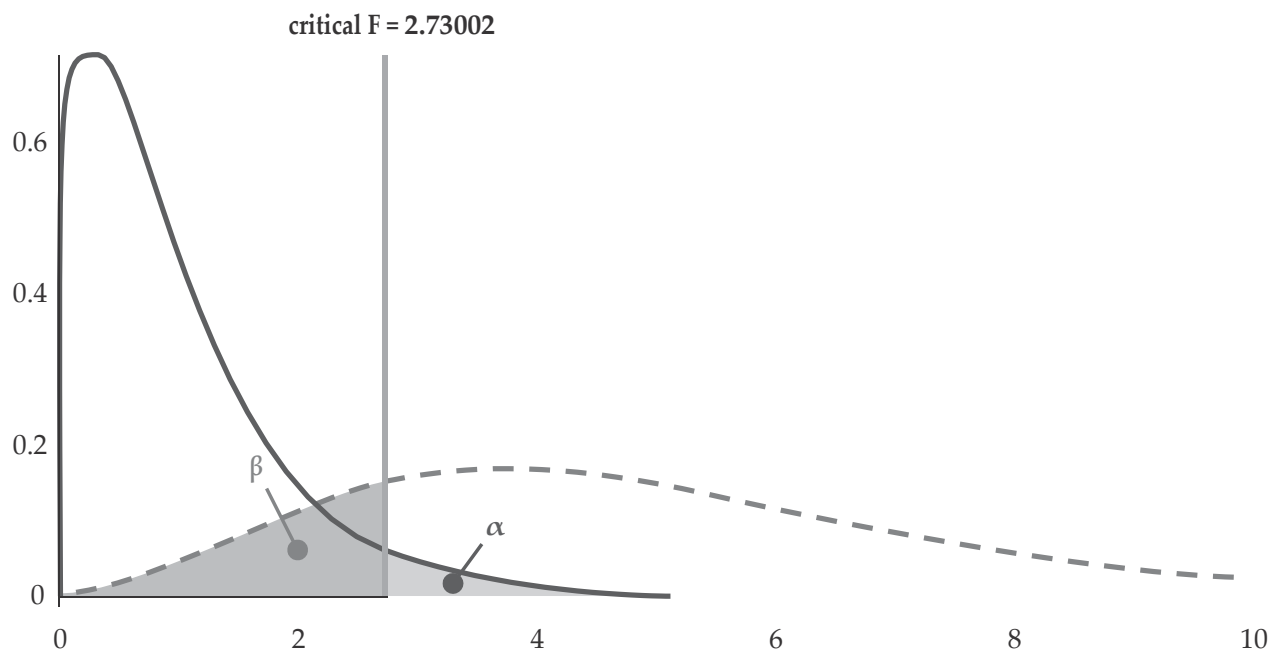

Figure 5. G*Power

Sample Size 
The respondents must be micro-entrepreneurs, users of Islamic financial technology, and have a rudimentary knowledge of technology. The purposive sampling method was preferred, as respondents were selected based on the researcher's knowledge of the population and what type of sample would best suit their goals (Wolfer, 2007). The questionnaire design is adopted and adapted from previous research. The completed data were screened and coded accordingly. 107 questionnaires were returned and seven were discarded because of redundant and/or incomplete answers. The completed data were sufficient for analysis using Amos (SEM). The questionnaire was written in both English and Malay, with back translation used for the translation (De Run \& Ting, 2006).

\subsection{Model Development}

Considering both the theoretical and empirical review, a model of Islamic financial technology (i-fintech) was developed in order to understand relevant key issues. Based on the literature review, there are three variables that may encourage i-fintech use, namely crowdfunding, mobile money, and peer-to-peer lending. It should be noted that no previous studies have reported on factors related to sustainability income. In order to fit with the current research context, only these three factors were selected for the study.

The variables were developed based on previous studies. The questionnaire was also adopted and adapted from earlier studies, such as those of Boomsiritomachai et al. (2017), Yu (2014), Venkatesh et al. (2003) and Laforet and Li (2005). The details of the latent variables used are shown in Table 5. It is hypothesised that crowdfunding, mobile money and peer-to-peer lending have positive significant relationships with sustainable income. To understand the dynamics between these variables, the following method was adopted to achieve the study objectives.

\subsection{Method}

A structural equation model (SEM) was employed, specifically the analysis of moment structure (AMOS) program to analyse the data. SEM has been employed for a relatively long time, and in recent years has gained a place as one of the most widely used statistical tools in certain areas of social science research (Hair et al., 2007). As stated by Anderson and Gerbing (1988), one reason for this is because it offers great potential for furthering theory development. Basically, SEM is described as a statistical methodology that takes a confirmatory (hypothesis testing) approach to analyse proposed study frameworks. SEM tests the entire model, not just part of it. The complete model is therefore either accepted or rejected; in other words, the model either fits the data or does not.

In short, SEM was selected for this study for several reasons. First, it permits the operation of multiple indicators to measure constructs and to condense measurement errors by having multiple indicators for each latent variable (Bryne, 2010). Second, it is able to assess causal relationships between multiple constructs concurrently (Jöreskog \& Sörbom, 1982). Third, SEM can generate awareness in the direction among study constructs, and to test how and to what degree variables affect each other (Judge \& Ferris, 1993). Fourth, it can propose a complete 
assessment of the fit of the proposed framework, and test the separate hypotheses rather than the coefficients, which is the case within multiple regressions. Basically, in SEM there are two phases. The first phase is known as the measurement model, which is tested using confirmatory factor analysis (CFA), while the second phase is the structural model, or SEM model or path diagram, which is measured using path analysis.

\section{RESULTS AND ANALYSIS}

\subsection{Results}

To measure the robustness of the model, a normality test was employed. According to Tabachnick and Fidell (2007), a numerical representative can be accessed through skewness and kurtosis produced by a normality test. The skewness value indicates symmetry, while the kurtosis value provides information about the peak of the distribution; therefore, if the distribution is perfectly normal, it will obtain a skewness value of 0 and kurtosis value of 3 (Kline, 2015). The values for both skewness and kurtosis in our model were within the recommended levels (see Table 3), suggesting univariate normality.

Table 3.

Normality Test

\begin{tabular}{lcccc}
\hline & Mean & SD & Skewness & Kurtosis \\
\hline SI1 & 7.9400 & 2.34766 & -1.293 & .986 \\
SI2 & 8.0900 & 2.12296 & -1.070 & .294 \\
SI3 & 8.2000 & 2.10819 & -1.207 & .619 \\
SI4 & 8.2700 & 2.12182 & -1.334 & .813 \\
MM1 & 8.5400 & 1.68427 & -1.235 & .864 \\
MM2 & 8.3700 & 1.70356 & -1.161 & .530 \\
MM3 & 8.1600 & 1.88947 & -1.262 & 1.426 \\
MM4 & 8.4800 & 1.74934 & -1.416 & 1.410 \\
MM5 & 8.5300 & 1.77215 & -1.189 & .516 \\
P2P1 & 5.5200 & 3.23953 & -.169 & -1.431 \\
P2P2 & 6.0700 & 3.13422 & -.365 & -1.274 \\
P2P3 & 5.9800 & 3.08132 & -.361 & -1.237 \\
P2P4 & 6.0000 & 3.16866 & -.391 & -1.264 \\
P2P5 & 5.7700 & 3.14580 & -.260 & -1.234 \\
CF1 & 7.8700 & 2.31226 & -1.119 & .635 \\
CF2 & 7.8500 & 2.23550 & -1.153 & .900 \\
CF3 & 7.8600 & 2.40378 & -1.007 & .143 \\
CF4 & 7.8500 & 2.39686 & -.992 & .138 \\
CF5 & 7.8300 & 2.34006 & -1.075 & .420 \\
\hline
\end{tabular}

After testing the robustness of the data, demographic factors such as gender, marital status, ethnicity, age, education level, and number of employees were analysed. As shown in Table 4, most of the respondents were female (72\%), with 
$28 \%$ male. The micro-entrepreneurs were predominantly married (65\%), with 29 percent single, and 6 percent widows. Table 5 shows that most of all the respondents were Malays. A significant proportion of the respondents were aged 41-50 years old, at 31 percent, followed by 31-40 years old, at 29 percent, 21-30 years old, at 27 percent, with the minority of i-fintech users, 13 percent, aged 51-60 .

Table 4.

Sample Characteristics

\begin{tabular}{lcc}
\hline Demographic Respondent & & Frequency [\%] \\
\hline Gender & Male & $28[28.0]$ \\
& Female & $72[72.0]$ \\
\hline Marital Status & Married & $65[65.0]$ \\
& Single & $29[29.0]$ \\
& Widows & $6[6.0]$ \\
\hline Ethnicity & Malay & $90[90.0]$ \\
& Chinese & $7[8.0]$ \\
Age & Indian & $3[3.0]$ \\
& $21-30$ & $27[27.0]$ \\
& $31-40$ & $29[29.0]$ \\
& $41-50$ & $31[31.0]$ \\
\hline Education Level & $51-60$ & $13[13.0]$ \\
& No formal education & $7[7.0]$ \\
& Primary school & $1[1.0]$ \\
& Secondary school & $70[70.0]$ \\
& Certificate/Diploma & $21[21.0]$ \\
& Bachelor's degree & $1[1.0]$ \\
\hline No. of Employees & No staff & $77[77.0]$ \\
& Fewer than 2 & $20[20.0]$ \\
& $2-3$ & $3[3.0]$ \\
\hline
\end{tabular}

Note. $\mathrm{N}=100$

\subsubsection{Measurement Model}

Table 5 outlines the factor analysis results. The criteria used to identify the loadings were that each item should load 0.50 or higher (Igbaria et al., 1995). The total variance explained was 86.524 percent, which indicates that the KMO was 0.885 , thus indicating sufficient intercorrelations, whereas the p-value for Bartlett's test was 0.000 for all the variables, which were perfectly significant as $(p<0.05)$. Communalities indicate the degree to which the factors explain the variance of the variables. Low values of commonalities that are less than 0.3 could indicate that the item does not fit well with the other items in its component. All the items had communality values above 0.5 , which means that they all had 50 percent of the variable variance explained (Table 5). One item was deleted to achieve the targeted variance. These items are CF1. The item was deleted due to it having the lowest values for communality, redundant factor loading, and low loading values. 
Table 5. Exploratory Factor

Analysis

\begin{tabular}{|c|c|c|c|c|c|}
\hline & CF & MM & P2P & SI & C \\
\hline $\begin{array}{l}\text { Crowdfunding can reduce the unemployment rate by offering } \\
\text { more jobs }\end{array}$ & .886 & & & & .939 \\
\hline Crowdfunding helps my business to go global & .870 & & & & .957 \\
\hline Crowdfunding is an attractive way to start a business & .869 & & & & .920 \\
\hline $\begin{array}{l}\text { Funds gathered from crowdfunding can assist me in } \\
\text { generating more income }\end{array}$ & .866 & & & & .897 \\
\hline Crowdfunding helps to raise my business capital & .818 & & & & .863 \\
\hline Mobile transfer allows me to complete a faster transaction & & .899 & & & .940 \\
\hline Mobile transfer helps me to keep track of my profit and loss & & .873 & & & .893 \\
\hline Mobile transfer keeps my transactions up to date & & .828 & & & .836 \\
\hline $\begin{array}{l}\text { Mobile transfer helps to provide evidence for my business } \\
\text { transactions }\end{array}$ & & .801 & & & .784 \\
\hline Mobile transfer can work 24/7 without problem & & .712 & & & .579 \\
\hline Peer-to-peer lending helps to increase my business assets & & & .949 & & .978 \\
\hline Peer-to-peer lending helps to narrow my income gap & & & .929 & & .949 \\
\hline Peer-to-peer lending helps my business productivity & & & .898 & & .883 \\
\hline Peer-to-peer lending helping me to be an entrepreneur & & & .851 & & .759 \\
\hline $\begin{array}{l}\text { Peer-to-peer lending has lower transaction costs in matching } \\
\text { financing }\end{array}$ & & & .728 & & .657 \\
\hline Islamic financial technology helps my business expansion & & & & .760 & .953 \\
\hline $\begin{array}{l}\text { Islamic financial technology helps my business to grow } \\
\text { inclusively }\end{array}$ & & & & .744 & .933 \\
\hline Islamic financial technology helps to diversify my business & & & & .675 & .855 \\
\hline$\%$ of variance $(86.524)$ & 25.643 & 25.159 & 24.418 & 11.304 & \\
\hline Keiser Meyer Olkin Measure & & & & .885 & \\
\hline Bartlett's Test & & & & 0.000 & \\
\hline
\end{tabular}

Note: $\mathrm{CF}=$ Crowdfunding; $\mathrm{MM}=$ Mobile Money; P2P = Peer-to-peer Lending; $\mathrm{SI}=$ Sustainable Income; $\mathrm{C}=$ Communalities.

As an extension of exploratory factor analysis (EFA), further investigation was made by analysing the confirmatory factor analysis (CFA) model, with the results presented in Figure 5. There are four constructs with at least three items in each. As proposed by Kline (2015), the standard CFA model with a single factor has at least three indicators; the model is identified . Therefore, this model is identified and tested for model fitness.

In term of model fitness, for a good fit the Chi-square normalised by degrees of freedom should not exceed 3; the goodness of fit index (GFI) should exceed 0.9 (Joreskog \& Sorbom, 1984); the adjusted goodness of fit index (AGFI) should exceed 0.8 (Tanaka \& Huba, 1985); the normed fit index (NFI) should exceed 0.9 (Bollen, 1989); the comparative fit index (CFI) should exceed 0.9 (Bentler, 1990); and the root mean squared error (RMSEA) should be in the range of 0.08 to 0.10 (Brown \& Cudeck, 1993). Based on the goodness of fit indices (Figure 6), this measurement model has adequate model fit indices and achieves unidimensionality after removing both the lower factor loading (less than 0.5) and $\mathrm{R}^{2}$ lower than 0.4 , namely items MM1 and CF1. 


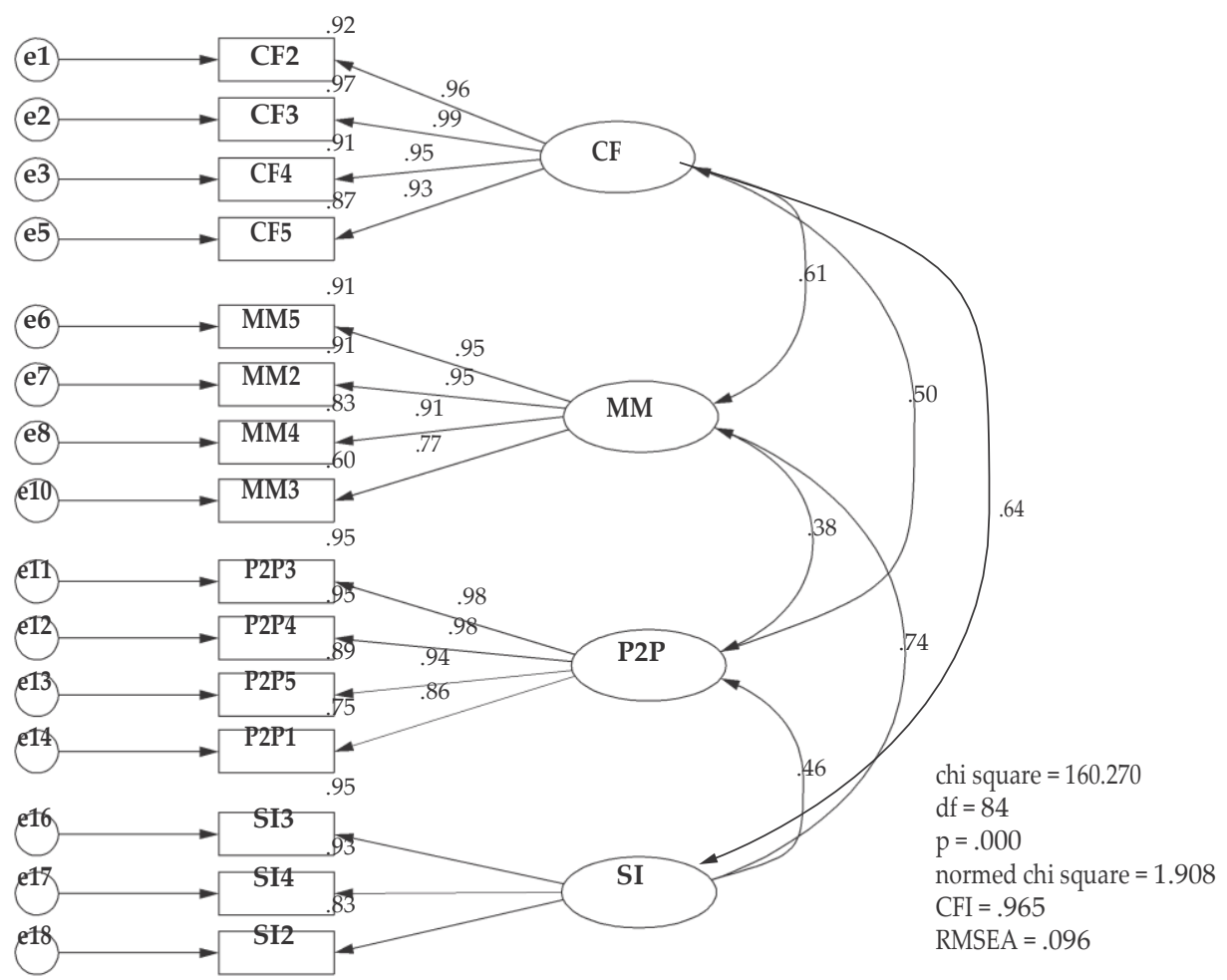

Figure 6.

\section{Confirmatory Factor Analysis}

Once the targeted goodness of fit indices were achieved, the model was further investigated using model evaluation, reliability, and validity test (Table 6). The reliability values (CR) are all above 0.7 , interpreted like a Cronbach's alpha for internal consistency reliability estimate, composite reliability of 0.70 , and higher is considered acceptable (Nunnally, 1978). Composite reliability (CR) and average variance extracted (AVE) were employed to assess the convergent validity. The recommended values for both are 0.5 , and the loadings for all items exceeded this level (Hair et al., 2010). Convergent validity refers to the extent to which items appear to be indicators of a single underlying construct and is assessed by the presence of significant factor loadings and NFI>0.90. Next, the study tested for discriminant validity, which measures the degree to which items are differentiated among constructs (Tojib, Sugianto \& Sendjaya, 2008). As indicated in Table 6, the squared correlation for each construct was less than the average variance extracted (AVE) by the indicators measuring that construct, indicating adequate discriminant validity.

The measurement model established discriminant validity as the MSV of all individual constructs was found to be lower than their respective AVE estimates ( 
Table 6.

Model Evaluation

\begin{tabular}{lcccccccc}
\hline & CR & AVE & MSV & MaxR(H) & SI & CF & MM & P2P \\
\hline SI & 0.966 & 0.903 & 0.554 & 0.974 & $\mathbf{0 . 9 5 0}$ & & & \\
CF & 0.978 & 0.918 & 0.411 & 0.985 & 0.641 & $\mathbf{0 . 9 5 8}$ & & \\
MM & 0.945 & 0.813 & 0.554 & 0.964 & 0.744 & 0.610 & $\mathbf{0 . 9 0 2}$ & \\
P2P & 0.968 & 0.884 & 0.254 & 0.980 & 0.464 & 0.504 & 0.378 & $\mathbf{0 . 9 4 0}$ \\
\hline
\end{tabular}

Note. $\mathrm{CR}=$ composite reliability; $\mathrm{AVE}=$ average variance extracted, $\mathrm{MSV}=$ maximum shared variance, $\mathrm{ASV}=$ average shared squared variance

4.1.2. Structural Model The study next tested the hypotheses proposed using structural equation modeling (SEM); the results are shown in Figure 7 . These indicate that crowdfunding $(\beta=0.336, p<0.01)$, mobile money $(\beta=0.547$, $\mathrm{p}<0.01)$, and peer-to-peer ending $(\beta=0.137, \mathrm{p}<0.10)$ positively influenced the sustainable income (SI) of micro- entrepreneurs. The $\mathrm{R}^{2}$ of 0.62 means that 62 percent of the sustainable income from using i-fintech could be estimated by using these three constructs.

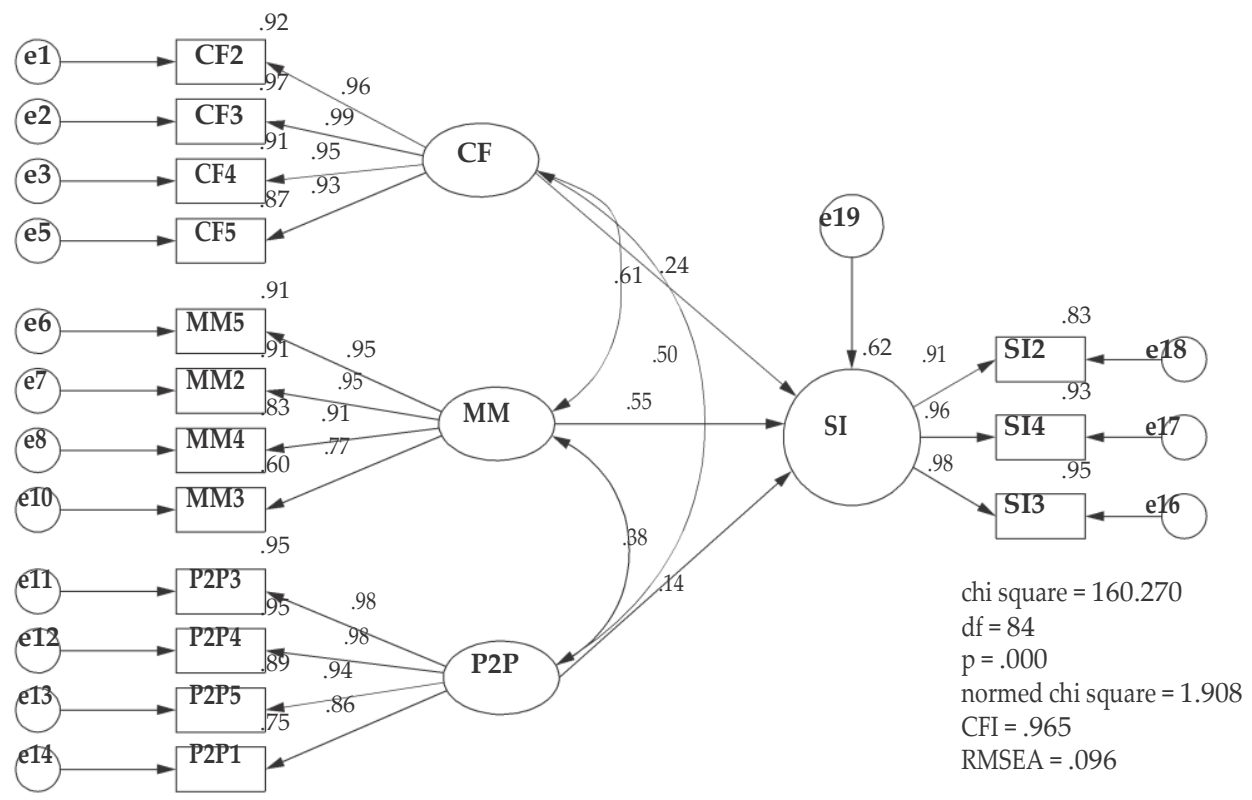

Figure 7.

Structural Equation Modeling

Therefore, hypotheses H1-H3 (Table 7) are supported. Upon further scrutiny, the model also shows that mobile money (MM) is the most significant predictor of sustainable income for micro-entrepreneurs, given its high coefficient of determination. 
Table 7. Hypothesis

Results

\begin{tabular}{lccc}
\hline Hypothesis & SD estimate & P-value & Result \\
\hline $\begin{array}{l}\text { H1. Crowdfunding (CF) has a positive and significant } \\
\text { relationship with sustainable income (SI) for micro- } \\
\text { entrepreneurs. }\end{array}$ & 0.087 & $0.009^{*}$ & Supported \\
\hline $\begin{array}{l}\text { H2. Mobile money (MM) has a positive and significant } \\
\text { relationship with sustainable income (SI) for micro- } \\
\text { entrepreneurs. }\end{array}$ & 0.106 & $0.000^{*}$ & Supported \\
\hline $\begin{array}{l}\text { H3. Peer-to-peer lending (P2P) has a positive and } \\
\text { significant relationship with sustainable income (SI) } \\
\text { for micro-entrepreneurs. }\end{array}$ & 0.053 & $0.074^{* * *}$ & Supported \\
\hline
\end{tabular}

Note: ${ }^{*}, * *$ and ${ }^{* * *}$ denote significance at levels of $1 \%, 5 \%$, and $10 \%$ respectively.

\subsection{Analysis and Discussion}

In general, the use of TAM in the current context was supported and extended by this study. It has been ascertained that there are at least three factors that promote sustainable income growth for micro-entrepreneurs that can be added to the existing body of work.

First, the significant 'mobile money-sustainable income growth ' relationship provides strong support for the use of mobile money among micro-entrepreneurs in securing a sustainable source of income. Conversely, little or no use of mobile money weakens the relationship. This finding is in line with Rysman and Schuh (2016) and Cochrane (2014), who stated that mobile money would generate capital gains and assist financial stability. This can be partly explained by the continuous push by commercial banks and even the Bank Negara Malaysia for Malaysians to go cashless. The highly significant finding also provides support for the literature pointing to the various benefits of mobile money, such as increased revenue (Rinder \& Fiserv, 2016) and convenience for both transacting parties (Anderson, 2010). This suggests valid ways of improving capital in conducting business, with some impact being shown on the real economy.

Second, the significant 'crowdfunding-sustainable income growth relationship also provides strong empirical support for the research model. Second only to the mobile money factor, the results highlight the importance of an alternative form of financing among micro-entrepreneurs in Malaysia. In general, most micro-entrepreneurs start their businesses using their own internal sources of funds. However, as with any business, expansion usually entails the need for capital. More importantly, in order to sustain any increase in demand, external sources of funds are generally warranted. The literature also points to the fact that most micro-entrepreneurs lack what the commercial banks are looking for strong credit ratings.

Crowdfunding therefore, helps to mitigate this mismatch as its nature is project- or individual-specific. Hence, the research has found a strong correlation between these two variables, which is encouraging given the novelty of the concept in Malaysia. In fact, as highlighted by Kauffman et al. (2012), crowdfunding could shine a light on the need of people for a sustainable income. Moreover, Moleskis et al. (2016) also mention the positive contribution of crowdfunding towards income 
stability. In fact, the project-specific nature of crowdfunding also helps funders to carefully select their investment portfolio, especially Syariah-conscious investors. Projects that are Syariah-compliant, with robust ethical premises, will be more likely to receive funding. The onus therefore falls upon micro-entrepreneurs to tap into this vast potentiality of crowdfunding by highlighting how their projects or business ventures may add value to investors. This can be best achieved either through lending-based or equity-based crowdfunding (Griffin, 2012).

Third, the significant relationship between 'peer-to-peer lending-sustainable income growth ' also provides strong empirical support for the research model. This was supported by previous studies such as thjose of Ge et al. (2017) and Jiang et al. (2018). Unlike conventional business loans, or any loans for that matter, Syariah-compliant financing is operated on three basic premises: the prohibition of riba' (usury), maysir (gambling) and gharar (uncertainty). Consequently, P2P lending that involves these prohibitive elements must be avoided at all costs. For example, P2P financing that promises fixed interest in return for loans and/or charges on late payments is not considered as a Syariah-compliant P2P financing platform.

\section{CONCLUSION AND RECOMMENDATIONS}

\subsection{Conclusion}

The use of Islamic financial technology (i-fintech) has enabled micro-entrepreneurs to expand and sustainably grow their businesses. In fact, by using specific i-fintech tools, micro-entrepreneurs can have a macro-level view of the information concerning their current state of finances. This has indirectly increased their income, allowed them to gain and retain more customers, reduced their cost structure, and mitigated their risks. All of these factors are certain to enhance micro-entrepreneurs' productivity and efficiency in conducting their business. Further studies, enhancement and evaluation are definitely needed to provide greater understanding of other potential factors that may affect the dynamics between i-fintech and sustainable income, especially for micro-entrepreneurs, and will hopefully provide useful guidelines for practitioners, regulators, academicians and i-fintech system designers.

\subsection{Recommendations}

The findings of this study provide both theoretical and managerial implications in comprehending the determinants of sustainable income growth in Malaysia. The research will help practitioners, researchers and regulators to have better understanding of the dynamics between the potential of i-fintech and sustainable income. Practitioners, including start-ups, Islamic financial institutions and system designers, will have new input related to i-fintech. In fact, i-fintech could be a valuable intangible (with unlimited transactions) product for them.

On the other hand, regulators or policymakers should create incentives that will encourage more practitioners to apply i-fintech in their business. At the same time, policymakers should encourage i-fintech institutions to promote low financing leverage from the start. This could create and maintain a simple and transparent system. 
Academicians should be involved in studying and researching the potential of i-fintech in depth, especially how i-fintech could benefit the bottom line community, especially those in B30, B20 and B10. In addition, academicians also need to consider other potential theories closely related to i-fintech, such the combination of the technology acceptance model (TAM) and behavioural finance theory.

\section{REFERENCES}

Alaa Alaabed, F., \& Mirakhor, A. (2017). Accelerating Risk Sharing Finance via FinTech: NextGen Islamic Finance. In The 1st International Colloquium on Islamic banking and Finance (pp. 1-10).

Alufohai, G. O. (2006). Sustainability of Farm Credit Delivery by Cooperatives and NGOs in Edo and Delta States, Nigeria. Educational Research and Reviews, 1(8), 262-266.

Anderson, J. (2010). M-banking in Developing Markets: Competitive and Regulatory Implications. info, 12(1), 18-25.

Anshari, M., Almunawar, M. N., Masri, M., \& Hamdan, M. (2019). Digital Marketplace and FinTech to Support Agriculture Sustainability. Energy Procedia, 156, 234-238.

Beck, T., Demirguc-Kunt, A., \& Levine, R. (2004). Finance, Inequality and Poverty. World Bank Policy Research Working Paper, 3338.

Belleflamme, P., Lambert, T., \& Schwienbacher, A. (2013). Individual Crowdfunding Practices. Venture Capital, 15(4), 313-333.

Bentler, P. M. (1990). Comparative Fit Indexes in Structural Models. Psychological Bulletin, 107(2), 238 .

Bollen, K. A. (1989). A New Incremental Fit Index for General Structural Equation Models. Sociological Methods E Research, 17(3), 303-316.

Boonsiritomachai, W., \& Pitchayadejanant, K. (2017). Determinants Affecting Mobile Banking Adoption by Generation Y Based on the Unified Theory of Acceptance and Use of Technology Model Modified by the Technology Acceptance Model Concept. Kasetsart Journal of Social Sciences .

Brau, J. C., \& Woller, G. M. (2004). Microfinance: A Comprehensive Review of the Existing Literature. The Journal of Entrepreneurial Finance, 9(1), 1-28.

Brown, M., \& Cudeck, R. (1993). Alternative Ways of Assessing Model Fit. K. Bollen and $J$.

Costa, A., \& Ehrbeck, T. (2015). A Market-Building Approach to Financial Inclusion. Innovations: Technology, Governance, Globalization, 10(1-2), 53-59.

Darmansyah, A., Nasution, R. A., Sutardi, A., \& Zen, T. S. (2013). Microfinance Institutions (MFIs) Profit Sharing Pattern for the Development of Micro and Small Enterprises (MSEs) in Indonesia. Jurnal Teknologi, 64(2).

Dash, M., Bhusan, P. B., \& Samal, S. (1970). Determinants of Customers $\tilde{A} \lessdot \hat{A} \hat{A}$ Adoption of Mobile Banking: An Empirical Study by Integrating Diffusion of Innovation with Attitude. The Journal of Internet Banking and Commerce, 19(3), $1-21$.

De Run, E. C., \& Ting, P. L. (2006). Estimating the Probability of Service Recovery Strategies in Franchise Fast Food Restaurant. Labuan Bulletin of International Business and Finance, 4, 95-108. 
Feng, Y., Fan, X., \& Yoon, Y. (2015). Lenders And Borrowers' Strategies In Online Peer-To-Peer Lending Market: An Empirical Analysis Of Ppdai. Com. Journal Of Electronic Commerce Research, 16(3), 242.

Forbes, W., \& Hodgkinson, L. (2015). Institutional Investors. In Corporate Governance in the United Kingdom: Past, Present and Future (pp. 41-49). London: Palgrave Pivot.

Fuad, N., \& Bohari, A. M. (2011). Malay Women Entrepreneurs in the Small and Medium Sized ICT-Related Business: A Study on Need for Achievement. International Journal of Business and Social Science, 2(13).

Gerber, E. M., Hui, J. S., \& Kuo, P. Y. (2012). Crowdfunding: Why People are Motivated to Post and Fund Projects on Crowdfunding Platforms. In Proceedings of the International Workshop on Design, Influence, and Social Technologies: Techniques, Impacts and Ethics 2(11), Northwestern University Evanston, IL.

Ge, R., Feng, J., Gu, B., \& Zhang, P. (2017). Predicting and Deterring Default with Social Media Information in Peer-to-Peer Lending. Journal of Management Information Systems, 34(2), 401-424.

Ghazali, N. H., \& Yasuoka, T. (2018). Awareness and Perception Analysis of Small Medium Enterprise and Start-up towards FinTech Instruments: Crowdfunding and Peer-to-Peer Lending in Malaysia. International Journal of Finance and Banking Research, 4(1), 13 .

Griffin, Z. J. (2012). Crowdfunding: Fleecing the American Masses. Case W. Res. JL Tech. E Internet, 4, 375 .

Hemer, J. (2011). A Snapshot on Crowdfunding (No. R2/2011). Working papers firms and region .

Hui, H. W., Manaf, A. W. A., \& Shakri, A. K. (2019). Fintech and the Transformation of the Islamic Finance Regulatory Framework in Malaysia. Emerging Issues in Islamic Finance Law and Practice in Malaysia, Emerald Publishing Limited, 211 -222.

Igbaria, M., Guimaraes, T., \& Davis, G. B. (1995). Testing the Determinants of Microcomputer Usage via a Structural Equation Model. Journal of Management Information Systems, 11(4), 87-114.

Jiang, Y., Ho, Y. C., Yan, X., \& Tan, Y. (2018). Investor Platform Choice: Herding, Platform Attributes, and Regulations. Journal of Management Information Systems, 35(1), 86-116.

Joreskog, K. G., \& Sorbom, D. (1984). LISREL VI: Analysis of Linear Structural Relationships by the Method of Maximum Likelihood. Mooresville, IN: Scientific Software .

Kaplinsky, R. (2019). Technology and Innovation for Sustainable Development. In The Palgrave Handbook of Development Economics (pp. 589-626). Palgrave Macmillan, Cham.

Laforet, S., \& Li, X. (2005). Consumers' Attitudes towards Online and Mobile Banking in China. International Journal of Bank Marketing, 23(5), 362-380.

Lee, T. H., \& Kim, H. W. (2015). An Exploratory Study on Fintech Industry in Korea: Crowdfunding Case. In 2nd International Conference on Innovative Engineering Technologies (ICIET'2015). Bangkok.

Meuter, M. L., Ostrom, A. L., Roundtree, R. I., \& Bitner, M. J. (2000). Self-Service Technologies: Understanding Customer Satisfaction with Technology-Based Service Encounters. Journal of Marketing, 64(3), 50-64. 
Mohammed, M. O., \& El Amri, M. C. (2019). Fintech In The Light Of Maqāsid AlSharī 'Ah. Fintech In Islamic Finance: Theory And Practice .

Moleskis, M., \& Canela, M. Á. (2016). Crowdfunding Success: The Case of Kiva. org .

Morse, A. (2015). Peer-to-Peer Crowdfunding: Information and the Potential for Disruption in Consumer Lending. Annual Review of Financial Economics, 7, 463482.

Nel, J., \& Boshoff, C. (2014). The Impact of Cross-Channel Cognitive Evaluations on the Continued Use Intentions of Mobile Banking. Management Dynamics: Journal of the Southern African Institute for Management Scientists, 23(4), 2-18.

Nik Azman, N. H., Kassim, S., \& Adeyemi, A. A. (2016). Role of Ar-Rahnu as MicroCredit Instrument in Achieving Financial Self-Sufficiency among Women Micro-Entrepreneurs. Intellectual Discourse, 24 .

Ordanini, A., Miceli, L., Pizzetti, M., \& Parasuraman, A. (2011). Crowd-Funding: Transforming Customers into Investors through Innovative Service Platforms. Journal of Service Management, 22(4), 443-470.

Oseni, U. A., \& Ali, S. N. (Eds.). (2019). Fintech in Islamic Finance: Theory and Practice. Routledge.

Rinder, J. M., \& Fiserv, S. W. (2016). The Importance of Website Usability Testing. [accessed 20 September 2016 ].

Schwienbacher, A., \& Larralde, B. (2010). Crowdfunding of Small Entrepreneurial Ventures. Handbook of Entrepreneurial Finance, Oxford University Press, Forthcoming :

Shaikh, A. A., \& Karjaluoto, H. (2015). Mobile Banking Adoption: A Literature Review. Telematics and Informatics, 32(1), 129-142.

Talukder, M., Quazi, A., \& Sathye, M. (2014). Mobile Phone Banking Usage Behaviour: An Australian Perspective. Australasian Accounting, Business and Finance Journal, 8(4), 83-104.

Tanaka, J. S., \& Huba, G. J. (1985). A Fit Index for Covariance Structure Models Under Arbitrary GLS Estimation. British Journal of Mathematical and Statistical Psychology, 38(2), 197-201.

Thye Goh, T., Mohd Suki , N., \& Fam, K. (2014). Exploring a Consumption Value Model for Islamic Mobile Banking Adoption. Journal of Islamic Marketing, 5(3), 344-365.

Todorof, M. (2018). Shariah-Compliant Fintech in the Banking Industry. In ERA Forum (Vol. 19, No. 1, pp. 1-17). Springer Berlin Heidelberg.

Wolfer, L. (2007). Real Research: Conducting and Evaluating Research in Social Sciences. Boston, MA: Pearson.

Worthington, R. L., \& Whittaker, T. A. (2006). Scale Development Research: A Content Analysis and Recommendations for Best Practices. The Counseling Psychologist, 34(6), 806-838.

Yang, Y., Liu, Y., Li, H., \& Yu, B. (2015). Understanding Perceived rRsks in Mobile Payment Acceptance. Industrial Management \& Data Systems, 115(2), 253-269.

Yu, C. S. (2014). Consumer Switching Behavior from Online Banking to Mobile Banking. International Journal of Cyber Society and Education, 7(1), 1-28. 
This page is intentionally left blank 